\title{
Orthoptera of the peat bogs and wet mountain grasslands in Orava region (NW Slovakia)
}

\author{
Anton KRIŠTíN, Anna SLIACKA and Benjamín JARČUŠKA \\ Institute of Forest Ecology SAS, Sturova 2, 96053 , Zvolen, Slovakia, \\ e-mail:kristin@savzv.sk
}

\begin{abstract}
Peat bogs are habitats of European importance, but only few data exists on crickets and grasshoppers living in these habitats. Altogether 22 species of Orthoptera (6 Tettigonioidea, 2 Tetrigoidea and 14 Acrididoidea) were found in 16 selected localities, in peat bogs and wet mountain meadows in the Orava region in 2008-2011. Only 16 species were registered in peat bogs ( 4 Tettigonioidea, 2 Tetrigoidea and 10 Acrididoidea) and 18 species in wet mountain meadows. Number of species per site varied between 2 and 14 (mean 9.5). The euryoecious species Euthystira brachyptera ( $\mathrm{F}=100 \%$ of sites), Metrioptera roeselii and Omocestus viridulus (both $93.8 \%$ ), Chorthippus apricarius $(87.5 \%)$ and Chorthippus parallelus $(75 \%)$ were the most frequent species. Mountain species Miramella alpina and Metrioptera brachyptera are indicators of specific mountain bilberry meadows and pet bogs. In this extremely cold area we expected wing dimorphic individuals (macropterism) in some brachypterous species. The highest number of macropters was found in Chrysochraon dispar, especially in peat bogs ecotones of the Rudné Nature Reserve $(26.8 \%)$ Occurrence, distribution and macropterism in some brachypterous species are commented.
\end{abstract}

Key words: grasshoppers, crickets, peat bogs, macropters, Slovakia

\section{INTRODUCTION}

Peat bogs and especially active raise bogs are habitats of European importance (Viceníková \& Polák 2003). However, there is little data on occurrence and structure of Orthoptera living in these habitats (c.f. Detzel 1998, Hochkirch \& Adorf 2007). We can find more information concerning Orthoptera from mountain meadows and their response to environmental factors and management (cf. Krištín \& Hrúz 2005, Fabriciusová et al. 2007, Marini et al. 2008, 2009).

Northern Slovakia is a region with very little known orthopterofauna. The orthopterocoenoses in this area are known mainly due to several research papers on Tatra Mts. (Ebner 1914, Chládek 1986, Krištín 2010). Some data on the orthopterofauna of NW Slovakia can be found in works from the Liptov region (Šušlík 1986), and the Chočské vrchy Mts. (Krištín 1996). There is comprehensive information from the adjacent area of southern Poland, Beskid Zachodni (Bazyluk \& Liana 2000). The structure of orthopterocoenoses in peat bogs from Slovakia has been less investigated and the knowledge in this mountain habitats is mostly fragmental (Straka 1992, 1993). The studied areas exhibit characteristics of cold forest complexes, primarily spruce forests, fragments of mountain meadows and, particularly, specific peat bogs (Trnka 2000). It is known that factors such as high moisture content and low temperature can be effective triggers for the high proportion of macropterous individuals in some brachypterous species (e.g. M. roeselii, M. brachyptera, E. brachyptera, Ch. dispar Ingrisch \& Köhler 1998, Poniatowski \& Fartmann 2011).

In this context, we have analysed the qualitative and quantitative structure of Orthoptera assemblages of mountain meadows and peat bogs of NW Slovakia, with focus on protected areas and sites of European importance. Another aim was to contribute to the knowledge of 
relations between the individual Orthoptera species and the specific peat bogs habitats. Proportion of macropters in some brachypterous species in these cold habitats is also discussed.

\section{MATERIAL AND METHODS}

Orthopterans were registered in 16 sites in the Orava area, always in August, during 20082011 (Fig. 1). The study localities were 1-2 ha in size and the time spent on each locality was 2-3 hours/control. The individual species of orthopterans were recorded visually and acoustically, the sampling was made by sweeping and beating from tree and shrub branches. The sampled species were identified according to HARZ $(1969,1975)$, and KOČÁREK et al. (2005), from whom we adopted also the nomenclature. For the quantitative evaluation of particular species we used relative frequency $(\mathrm{F} \%)$ and relative abundance. Percentage of macropters in short-winged (brachypterous) species was registered in all sites. As macropters we considered individuals with unworn tegmina and alae reaching or exceeding the length of postfemora (cf. Ramme 1931, Ingrisch \& Köhler 1998). For relative abundance of individual species on the study plots, we used ordinal scale described in Table 1. The relative semiquantitative abundance values in the results represent the highest numbers of adult individuals per one locality and one control (Table 1).

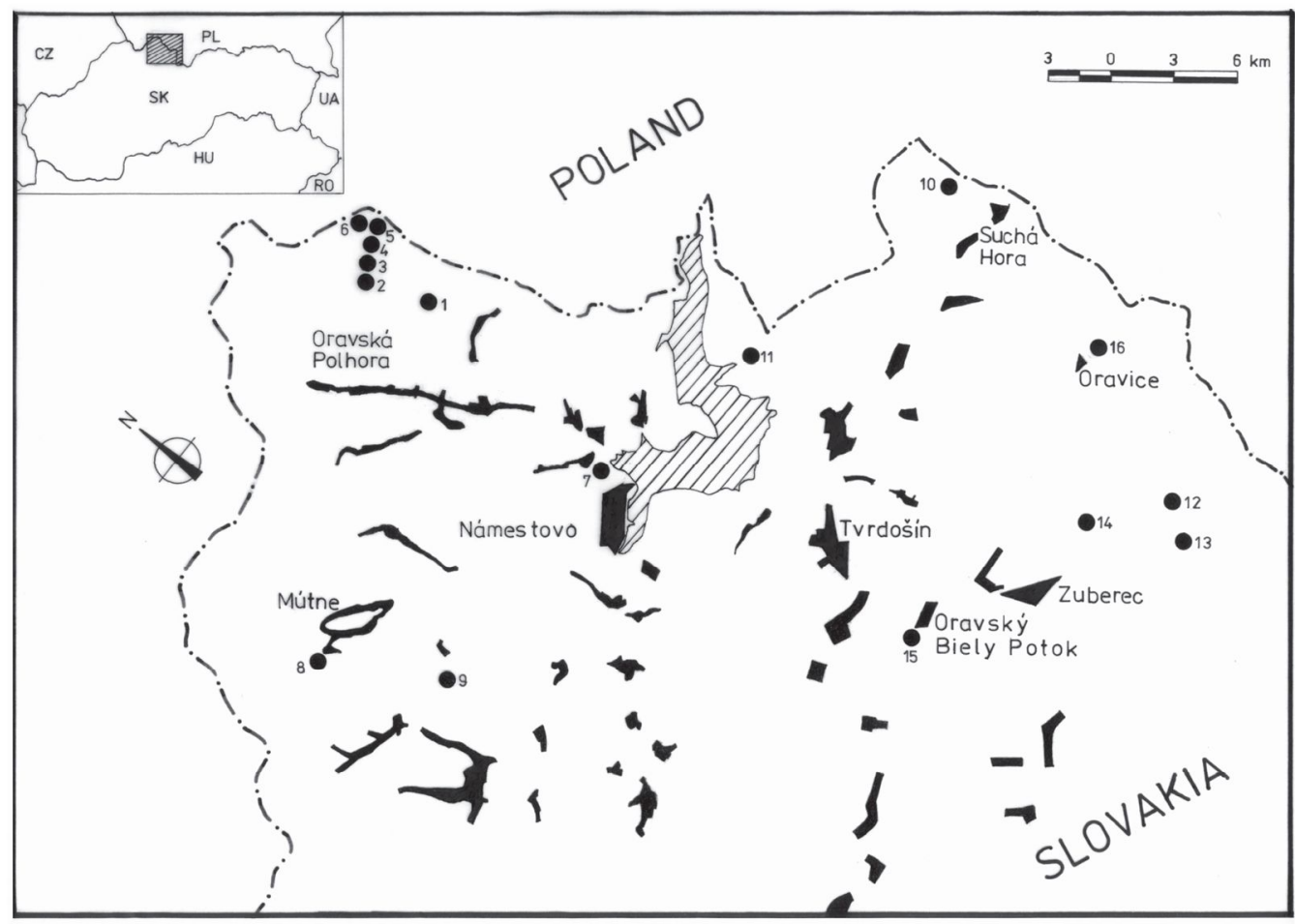

Fig. 1. Sketch of the 16 sites studied (black circles) in the Orava area with localisation within Slovakia (see numbers in chapter "Study sites"). Black patches indicate settlements, hatched plot - Orava Water reservoir, dash-dotted line border between Poland and Slovakia). 
Table 1. Relative abundance and frequency ( $\mathrm{F} \%$ ) of Orthoptera in 16 sites of the Orava area (NW Slovakia); site numbers as in the chapter "Study sites"; habitats: $\mathrm{G}$ - wet grasslands, $\mathrm{P}$ - peat bogs, $\mathrm{S}$ - grasslands on ski slopes; abundance: 1 - very rare species (less than 3 individuals), 2 - rare (3-10 ind.), 3 - abundant (11-100 ind.), 4 - very abundant (101 and more ind.); ${ }^{*}$ - brachypterous species with macropterous morph - see text.

\begin{tabular}{|c|c|c|c|c|c|c|c|c|c|c|c|c|c|c|c|c|c|}
\hline & \multicolumn{16}{|c|}{ Study site } & \multirow[b]{3}{*}{ Total } \\
\hline No. & 1 & 2 & 3 & 4 & 5 & 6 & $\begin{array}{l}77 \\
P\end{array}$ & $\begin{array}{l}8 \\
\mathrm{P}\end{array}$ & $\begin{array}{l}99 \\
\mathrm{P}\end{array}$ & $\begin{array}{c}10 \\
\mathrm{P}\end{array}$ & $\begin{array}{c}11 \\
\mathrm{P}\end{array}$ & 12 & 13 & 14 & 15 & 16 & \\
\hline $\begin{array}{c}\text { Habitat } \\
\text { Altitude }\end{array}$ & $\begin{array}{c}G \\
890\end{array}$ & $\begin{array}{c}\mathrm{G} \\
1170\end{array}$ & $\begin{array}{c}\mathrm{G} \\
1325\end{array}$ & $\begin{array}{c}\mathrm{G} \\
1550\end{array}$ & $\begin{array}{c}G \\
1670\end{array}$ & $\begin{array}{c}G \\
1700\end{array}$ & $\begin{array}{c}P \\
615\end{array}$ & $\begin{array}{c}\mathrm{P} \\
780\end{array}$ & $\begin{array}{c}\mathrm{P} \\
695\end{array}$ & $\begin{array}{c}\mathrm{P} \\
754\end{array}$ & $\begin{array}{c}P \\
645\end{array}$ & $\begin{array}{c}S \\
1080\end{array}$ & $\begin{array}{c}S \\
1400\end{array}$ & $\begin{array}{c}G \\
800\end{array}$ & $\begin{array}{c}G \\
640\end{array}$ & $\begin{array}{c}G \\
820\end{array}$ & \\
\hline Orthoptera species: & \multicolumn{16}{|c|}{ Abundance } & $\mathrm{F} \%$ \\
\hline Ensifera & & & & & & & & & & & & & & & & & \\
\hline Isophya camptoxypha (Fieber, 1853) & & & 2 & 1 & & & & & & & & 1 & 2 & & & & 25 \\
\hline Decticus vernicivorus (Linnaeus, 1958) & 3 & & & & & & & & & 3 & & 1 & 1 & & & 2 & 32.8 \\
\hline Metrioptera brachyptera (Linnaeus, 1758) & & & 1 & & & & & 3 & 2 & 2 & 2 & 4 & 2 & 3 & & 2 & 56.3 \\
\hline Metrioptera roeselii (Hagenbach, 1822)* & $3^{*}$ & $3^{*}$ & 2 & $2^{*}$ & 1 & & 3 & $3 *$ & $3 *$ & $4^{*}$ & 3 & 3 & 2 & 4 & 2 & 4 & 93.8 \\
\hline Pholidoptera griseoaptera (Degeer, 1773) & 1 & & & & & & & & & & & & & 1 & 1 & & 18.8 \\
\hline Tettigonia cantans (Fussli, 1775) & 3 & & & & & & 3 & 3 & 3 & 3 & 3 & & & 3 & 2 & 2 & 56.3 \\
\hline Caelifera & & & & & & & & & & & & & & & & & \\
\hline Tetrix bipunctata (Linnaeus, 1758) & & & & & & & & 2 & & & & & & & & & 6.3 \\
\hline Tetrix tenuicornis Sahlberg, 1893 & & & & & & & & & & 1 & & & & & 1 & 2 & 18.8 \\
\hline Miramella alpina (Kollar, 1833) & & & 2 & 3 & & & & & & & & & & & & & 12.5 \\
\hline Euthystira brachyptera (Ocskay, 1826)* & 4 & 4 & $4^{*}$ & $2 *$ & 1 & 1 & $4^{*}$ & $4^{*}$ & $4^{*}$ & $3^{*}$ & 3 & 2 & 1 & 4* & 2 & 3 & 100 \\
\hline Chorthippus albomarginatus (Degeer, 1773) & & 3 & 2 & & & & 4 & & & 4 & 2 & & & 1 & & & 56.3 \\
\hline Chorthippus apricarius (Linnaeus, 1758) & 4 & 2 & 3 & 2 & & & 3 & 4 & 2 & 3 & 2 & 2 & 1 & 3 & 2 & 2 & 87.5 \\
\hline Chorthippus biguttulus (Linnaeus, 1758) & 3 & 2 & & 1 & 1 & 1 & 2 & 2 & 2 & & & & & & & 2 & 56.3 \\
\hline Chorthippus brunneus (Thunberg, 1815) & & & & & & & & & & & & & & & & 1 & 6.3 \\
\hline Chorthippus dorsatus (Zetterstedt, 1821) & & & & & & & & & & 2 & 2 & & & 1 & & & 18.8 \\
\hline Chorthippus montanus (Charpentier, 1825) & & & 1 & 1 & & & 3 & 4 & & 3 & & 2 & 1 & 3 & 1 & 3 & 68 \\
\hline Chorthippus parallelus (Zetterstedt, 1821)* & 4 & $2^{*}$ & & & & & 2 & 2 & 2 & $3 *$ & 2 & 2 & 2 & $4^{*}$ & 2 & 3 & 75 \\
\hline Chrysochraon dispar (Germar, 1834)* & 1 & $3^{*}$ & & & & & & 2 & 1 & $3^{*}$ & $3^{*}$ & & & 1 & 1 & & 50 \\
\hline Omocestus haemorrhoidalis (Charpentier, 1825) & 1 & & & & 1 & & & & & & & & & & & & 12.5 \\
\hline Omocestus rufipes (Zetterstedt, 1821) & & 1 & & & & & & & & 2 & & & & 1 & & 1 & 25 \\
\hline Omocestus viridulus (Linnaeus, 1758) & 3 & 3 & 4 & 3 & 2 & & 3 & 4 & 2 & 3 & 3 & 4 & 4 & 4 & 3 & 2 & 93.8 \\
\hline Stenobothrus lineatus (Panzer, 1796) & & & & 1 & 1 & & & & & & & & & & & & 12.5 \\
\hline $\begin{array}{ll}\text { No. of species } \\
\end{array}$ & 11 & 9 & 9 & 9 & 6 & 2 & 9 & 11 & 9 & 14 & 10 & 9 & 9 & 13 & 10 & 12 & 9.5 \\
\hline
\end{tabular}




\section{STUDY SITES}

The study sites were situated in NW Slovakia, in the following land surface units: the Oravské Beskydy Mts; Oravská kotlina basin; Podbeskydská brázda basin, Skorušinské vrchy Mts, Podtatranská brázda basin and Západné Tatry Mts. These localities are situated along a vertical gradient ranging from 645 to $1710 \mathrm{~m}$ a. s. 1., in the alpine bioregion in basins and mountain chains in NW Slovakia $\left(49^{\circ} 13^{\prime}-34^{\prime} \mathrm{N}, 19^{\circ} 19^{\prime}-19^{\circ} 42^{\prime} \mathrm{E}\right)$. They mostly represent abandoned fragmented mountain meadows in spruce forests (sites 1-6, 14, 15), peat bogs (711) and ski pistes $(12,13)$ :

1. Hviezdoslavova horáreň, cadastral areas Oravská Polhora, Rabčice (890-900 m a.s.1., coordinates 49.32.27 N, 19.30.07E, Databank of Slovak Fauna, further DFS 6483) mesophilous to waterlogged, partially mown mountain meadows by the gamekeeper's house surrounded by spruce forests and mixed forests with Larix decidua, Salix spp., Fagus sylvatica, at about $5 \mathrm{~km}$ distance $\mathrm{N}$ from the Rabča village. The first locality of the vertical gradient Babia Hora (i.e. localities 1-6).

2. Mountain meadows on the southern boundary of the NNR "Babia Hora, c.a. Oravská Polhora (1150-1170 m a.s.1., 49.33.37 N, 19.30.00E, DFS 6483) - at about $2 \mathrm{~km}$ distance from the first locality, this locality is a scattered mountain meadow area in spruce forests with abundant occurrence of Vaccinium myrtilus on S and SW facing slopes.

3. Mountain meadows 1, c.a. Oravská Polhora (1325 m a.s.1., 49.33.55 N, 19.30.28E, DFS 6483 ) - similar mosaic mountain meadows on the vertical gradient Babia Hora (Site of community interest, further SCI 0189), situated at about $700 \mathrm{~m} \mathrm{NE}$ from the preceding locality, near the upper line of an open spruce forest, with abundant occurrence of Vaccinium myrtilus on S and SW facing slopes.

4. Mountain meadows 2, c.a. Oravská Polhora (1550 m a.s.1., 49.34.13 N, 19.31.07E, DFS 6483, SCI 0189) - another locality representing grassy-herbaceous stands on the vertical gradient Babia Hora, above the upper forest line in the dwarfpine and mountain-ash zone, at about $1000 \mathrm{~m}$ across spruce forest from the preceding site.

5. Alpine meadows, c.a. Oravská Polhora (1670 m a.s.1., 49.34.16 N, 19.31.43E DFS 6483, SCI 0189) - S facing alpine meadows on the vertical gradient of Babia Hora above the upper forest line and above the dwarfpine zone.

6. Babia hora, c.a. Oravská Polhora (1700-1710 m a.s.1., 49.34.21 N, 19.31.43E DFS 6483) - ridge rock habitats and dispersed grassy-herbaceous vegetation on SW facing slopes below the elevation point of the same name. The top of the regional vertical gradient of Babia Hora and NW Slovakia.

7. Klinské rašelinisko National Nature Reserve, c.a Klin, Slanica (615 m a.s.1., 49.25.43 $\mathrm{N}, 19.29 .48 \mathrm{E}$, DFS 6582, SCI 0191) - it is a typical active peatbog with assemblages of the unions Sphagnion, Sphagno recurvi-Caricion canescentis, Sphagno-Utricularion. The $\mathrm{N}$ and NE parts of this peat bog are relatively dry, with evident manifestations of secondary succession in form of natural seedlings of pioneer plant species, primarily birch (Betula sp.). Some of the typical species associated with peat bogs occurring in the waterlogged S and W parts are: Ledum palustre, Andromeda polifolia, Drosera rotundifolia, Oxycoccus palustris, Vaccinium uliginosum, Menyanthes trifoliata, Eriophorum sp.

8. Mútňanska píla Nature Reserve, c.a. Mútne (780 m a.s.1., 49.28.01 N, 19.17.24E, DFS 6581, SCI 0191) - peat bog in the stream valley of the Mútňanka stream, at $300 \mathrm{~m} \mathrm{~W}$ from the Mútňanská Píla village, with stands of Salix myrtilloides, in the herb layer with 
Oxycoccus palustris, Andromeda polifolia, Menyanthes trifoliata, Carex dioica, and Vaccinium uliginosum.

9. Beňadovské rašelinisko Nature Reserve, c.a. Beňadovo, Breza (695 m a.s.1., 49.25.12N, 19.19.46E, DFS 6581, SCI 0191) - peat bog with character similar to the preceding one, in the valley of the Mútnanka stream, at about $6 \mathrm{~km} \mathrm{SE}$ from the preceding locality. Apart from the species common for the all Oravian peat bogs, this locality exhibits rare sedges like Carex chorrdorhiza, C. lasiocarpa and C. limosa.

10. Rudné Nature Reserve, c.a. Suchá Hora (754 m a.s.1., 49.23.21 N, 19.46.49E, DFS 6684, SCI 0057) - peat bog degraded in its major part due to draining effects. In the preserved parts we found: Rhynchospora alba, Ledum palustre, Andromeda polifolia, Oxycoccus palustris, Calla palustris, Vaccinium uliginosum, and Empetrum nigrum. The lack of precipitations causes removal of the peat substrate cover which becomes slowly grown with Eriophorum vaginatum and Calluna vulgaris. A part of this locality exhibits ecotonal character with sufficient cover of dispersed shrubs and tree vegetation (willow, birch, pine).

11. Jelešn̆a National Nature Reserve, c.a Trstená (640-654 m a.s.1., 49.24.40 N, 19.37.52E, DFS 6583, SCI 0057) - transitory peat bogs and raised bogs in open spruce forests and waterlogged spruce forests (Vaccinio-Piceeion, Bazzanio-Piceetum, LeucobryoPiceetum).

12. Spálená 1, c.a. Zuberec (1080 m a.s.1., 49.14.14 N, 19.42.48E, DFS 6784) - permanent grasslands on the foothills of a ski slope.

13. Spálená 2, ), c.a. Zuberec (1400 m a.s.1., 49.13.25 N, 19.42.08E, DFS 6784) - permanent grasslands and forest meadows around the summit stop of the ski slope.

14. Zuberec, c.a. Zuberec (800 m a.s.1., 49.15.40 N, 19.37.55E, DFS 6783) - waterlogged mountain meadows in the valley of the Studený potok, stream with riparian willow vegetaion at about $1 \mathrm{~km} \mathrm{~V}$ from the village of Zuberec.

15. Oravský Biely Potok, c.a. of the same name (640 m a.s.1., 49.17.09 N, 19.31.41E, DFS 6783 ) - meadows bordering spruce forests and riparian stands of the equally named stream with irregular gravel terraces.

16. Oravice, c.a. Vitanová (820-840 m a.s.1., 49.24.40 N, 19.37.52E, DFS 6784) mezophilous mown meadows and pastures bordering $\mathrm{W}$ facing spruce forest stands above the village of the same name.

\section{RESULTS AND DISCUSSION}

\section{Qualitative and quantitative structure of Orthoptera assemblages}

In 16 sites in the Orava area (NW Slovakia,) we recorded altogether 22 Orthoptera species (representing only $17.9 \%$ of the Slovak orthopterofauna), comprising 6 Tettigonioidea, 2 Tetrigoidea and 14 Acrididoidea. Five peat bogs exhibited only 16 species (4 Tettigonioidea, 2 Tetrigoidea and 10 Acrididoidea) and the mountain meadows 18 species. These numbers are very low compared to some other mountain localities with dry pastures, meadows and more favourable habitats (such as the Pol'ana Mts., Krištín \& Hrúz 2005, Fabriciusová et al. 2007). In Orava mountain grasslands and peat bogs, we observed the absence of xerophilous and thermophilous species. Consequently, the low species number in Orava may be reasoned by the cold climate in this area, and by the low preference of the Orthoptera species for peat bogs and mountain meadows situated at higher altitudes. It is well known that low temperature, high soil moisture content, high air humidity, insufficient amount of solar radiation and long lasting winters with severe frost periods have negative impacts on the number of Orthoptera species and individuals, especially in peat bog habitats (Nadig 1981, 1997, Detzel 1998). 
The species number per site fluctuated between 2-14 (on average 9.6 species/ site) correlated with the habitat type and altitude. The highest number, 14 species were indentified in the peat bog Rudné; the lowest ( 2 species) in extreme cold grass stands around the summit of the Babia Hora Mt (1710 $\mathrm{m}$ a.s.l.). Grasshoppers (Caelifera) were dominant and more frequent than crickets (Ensifera) in all sites, due to the grassy - herbaceous character of vegetation structure in all sites (Fig. 2). The most frequent were the euryoecious species Euthystira brachyptera ( $\mathrm{F}=100 \%$ localities), Metrioptera roeselii and Omocestus viridulus (both 93.8\%), Chorthippus apricarius (87.5\%) and Chorthippus parallelus (at $75 \%$, Table 1 ). More that $50 \%$ frequency exhibited the grasshoppers Chorthippus montanus, Chorthippus albomarginatus, Chorthippus biguttulus, Chrysochraon dispar and the mountainous bushcrickets Metrioptera brachyptera and Tettigonia cantans. Even rarer were the mountainous species Miramella alpina and $M$. brachyptera. Surprising rarely, we found the bush-cricket Pholidoptera griseoaptera, widespread in forest ecotones of Central Europe and Chorthippus brunneus, Omocestus haemorrhoidalis, typical species of grasslands (Table 1). At the highest altitudes the species E. brachyptera and surprisingly also Ch. biguttulus were found. None of the species found was either protected or belonged to the Red List of Threatened Species in Slovakia (Krištín 2001).

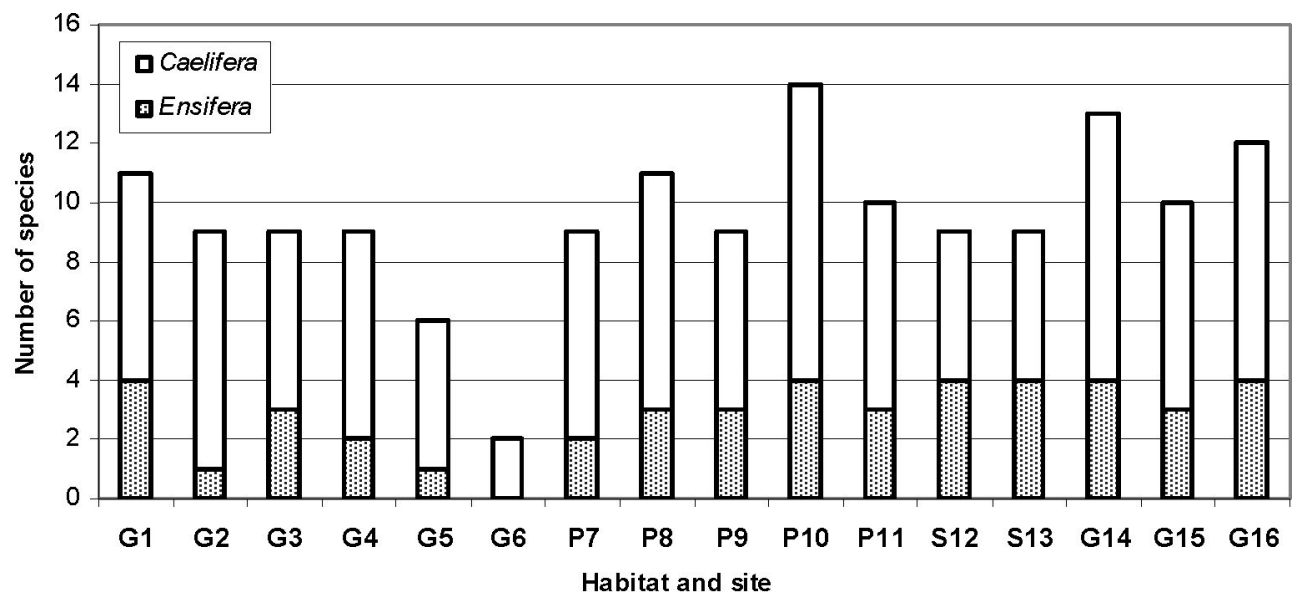

Fig. 2. Species numbers of Ensifera and Caelifera on 16 sites and three habitats ( $\mathrm{G}$ - mountain grasslands, $\mathrm{P}-$ peat bogs, $\mathrm{S}$ - grasslands on ski slopes) within Orava region (NW Slovakia).

In four primarily brachypterous species, we found macropterous morphs in some sites (Table 1). In Orthoptera, wing length and macropters can be important for the dispersal of individuals from a population located in extreme or new colonized habitats (Gardiner 2009; Poniatowski \& Fartmann 2011). It is known that currently macropters occur significantly more frequently than in past (Gardiner 2009) and populations with more than $20 \%$ macropters are no longer a rarity (Poniatowski \& Fartmann 2011). We registered general proportions of macropters under $5 \%$ out of all the checked individuals in most of the species (e.g. M. roeselii $2.8 \%$ from 438 checked individuals, E. brachyptera $3.1 \%$ from 356 , Ch. parallelus $5.1 \%$ from 116). However, in Chrysochraon dispar we found much higher proportions of macropters (11.8\% from 98 individuals), and even $26.8 \%$ from a total of 41 checked individuals at Rudné peat bog. There are only few data on macropterism in this species (e.g. Weidner 1955). Furthermore, we found no macropters in other registered brachypterous species, in which macropters are well known (e.g. M. brachyptera, Ch. montanus, cf. Ingrisch \& Köhler 1998). 


\section{Notes to occurrence and ecology of selected species}

Isophya camptoxypha - species registered in four sites, on boundaries between mountain meadows and spruce forests and in ecotones of grasslands covering ski pistes. The maximum abundance, represented by 4 males and 3 females, was found in a mountain meadow in Babia Hora (1325 m n.m.).

Metrioptera brachyptera - characteristic species for Oravian peat bogs and most of typical mountain and alpine meadows. It is an indicator species for peat bogs in various parts of Slovakia (Fabriciusová et al. 2007) and in Europe (Hochkirch 1997, Detzel 1998, Nielsen 2000).

Metrioptera roeselii - one of the most abundant and most frequent species in the studied area, in Babia Hora ascending up to $1625 \mathrm{~m}$ a.s.1.

Pholidoptera griseoaptera - low-in number and unexpected rare species in the studied habitats and localities.

Tettigonia cantans - regular and abundant species of peat bogs ( $>10 \mathrm{M} / 2 \mathrm{ha})$.

Tetrix bipunctata and Tetrix tenuicornis - less abundant species in the studied area. Another regular species in peat bogs, Tetrix undulata, has been reported from Germany (Hochkirch 1997, Detzel 1998) and is to be expected also in study area.

Miramella alpina - surprisingly, we found this species only in two sites situated in mountain bilberry meadows on the vertical gradient Babia Hora at altitude 1325-1550 $\mathrm{m}$ a.s.1.. It is a characteristic mountainous species of the altitudinal gradient of the Tatra Mts as ascending as high as $2200 \mathrm{~m}$ a.s.l. (Krištín 2010).

Chorthippus montanus - an abundant species in several peat bogs (Table 1), similarly as in Vel'ká Fatra Mts. (Straka 1992, 1993). For example, the highest abundance and dominance was found in the Mútňanské rašelinisko peat bog ( $>100 \mathrm{ex} / \mathrm{ha})$. The species was frequent on several mountain meadows in this area.

Omocestus viridulus - one of the most abundant and characteristic mountainous species of the study area, occurring regularly up to $1625 \mathrm{~m}$ a.s.1. (Babia Hora).

The prior faunistic works do not mention any more Orthoptera species than we have observed either in the Orava region or in the peat bogs of the Turiec region and the Vel'ká Fatra Mts. Straka $(1992,1993)$ recorded 6 and 7 euryoecious species in two petbogs of the Vel'ká Fatra Mts. and 6 common species in Oravský Podzámok hill (Straka 1998). Apart from the hitherto recorded species (see Table 1), we expect other species occurring in the neighbourhood mountain ranges, such as bushcricktes from the genus Isophya, Polysarcus denticauda (Charpentier, 1825) (on preserved mountain meadows in June-August), Barbitistes constrictus Br. v. Wattenwyl, 1878 (on spruce forest ecotones), Metrioptera bicolor (Philippi, 1830), Pholidoptera aptera (Fabricius, 1793), Tettigonia viridissima Linnaeus, 1758 (adjacent Tatra Mts), crickets Gryllotalpa gryllotalpa (Linnaeus, 1758) and Gryllus campestris Linnaeus, 1758 (Karaska D., in litt.), grasshoppers Podisma pedestris (Linnaeus, 1758), Gomphocerippus rufus (Linnaeus, 1758), Stethophyma grossum (Linnaeus, 1758), Stenobothrus stigmaticus (Rambur, 1838) (adjacent mountain ranges Liptov, Chočské vrchy, and Tatry, Šušlík 1986, Krištín 1996, 2010). Consequently, the ortopterofauna of the entire Orava region may involve more than 40 species, as only 54 localities in the Tatra Mts. exhibited altogether 45 species (Krištín 2010), and 8 localities in the Chočské vrchy Mts. and their surroundings 26 species (Krištín 1996). The data for the adjacent extensive area in Poland (Beskid Zachodni) have been summarised by Bazyluk \& Liana (2000) who identified there 42 species (16 Tettigonioidea, 2 Grylloidea and 24 Acridoidea).

The low number of species found in the studied habitats in the Orava region (representing only $17.9 \%$ from the total species number for Slovakia), as well as the above discussed cold tolerating indicator species of peat bogs and mountainous habitats document the cold climate of this region that does not meet requirements of the most Orthoptera species. The species 
protection also needs to consider problems associated with habitat endangering and with changes in their management. The primary case is the abandonment of traditional grazing and mowing practices, the secondary succession on mountain meadows on Babia Hora and, to some extent, also draining and former excavation of peat bogs in Orava (such as Rudné, Klin). One alternative of anti-successional protection is reintroduction of extensive sheep and goat grazing or periodical cleaning of the above-mentioned localities from natural seedlings of woody plants by mechanical cutting (min. at 5-10 year intervals).

\section{SUMMARY}

Peat bogs are habitats of Europaean importance, but there exists only few data on orthopterans living in these habitats. In total 22 species of Orthoptera (6 Tettigonioidea, 2 Tetrigoidea and 14 Acrididoidea) were found in peat bogs and wet mountain meadows in 16 selected localities in the Orava region during 2008-2011. Only 16 species were registered in peat bogs (4 Tettigonioidea, 2 Tetrigoidea and 10 Acrididoidea) and 18 species in wet mountain meadows. Number of species per site varied from 2-14, with a mean of 9.5 species per site. Euryoecious species Euthystira brachyptera ( $\mathrm{F}=100 \%$ of sites), Metrioptera roeselii and Omocestus viridulus (both 93.8\%), Chorthippus apricarius (87.5\%) and Chorthippus parallelus $(\mathbf{7 5 \%})$ were the most frequent species. Mountain species Miramella alpina and Metrioptera brachyptera were indicators of specific mountain bilberry meadows and peat bogs. In this extremely cold area we expected wing dimorphic individuals (macropterism) in some brachypterous species. The highest number of macropters was found in Chrysochraon dispar, especially in ecotones of peat bogs at the Rudné Nature Reserve (26.8\%). Occurrence, distribution and macropters in some brachypterous species are commented.

\section{ACKNOWLEDGEMENTS}

We express our thanks to P. Tuček, V. Fabriciusová and K. Dvořáčková for their assistance in the field work. This research has been granted from the projects VEGA No 2/0157/11 and No $2 / 0110 / 09$.

\section{REFERENCES}

BAZYLUK W. \& LIANA A. 2000. Prostoskrzydle (Orthoptera). Katalog fauny Polski. XVII. PWN, Warszawa, 2, 156 pp.

CHLÁDEK F. 1986. K vertikálnímu rozšírení rovnokřídlých (Orthoptera), švábů (Blattoptera) a škvorů (Dermaptera) v Belanských Tatrách. Zpravodaj Československé Společnosti entomologické ČSAV 22: 103-108.

DETZEL P. 1998. Die Heuschrecken Baden-Württembergs. Ulmer Verlag, Stuttgart, 580 pp.

EBNER R. 1914. Beitrag zur Kenntnis der Orthopteren - Fauna von Oesterreich - Ungarn. Internationale Entomologische Zeitschrift 7: 294-295, 309-312.

FABRICIUSOVÁ V., HRÚZ V., KRIŠTíN A. 2007. Rovnokrídlovce (Orthoptera) niektorých mokradných biotopov Pol'any. Naturae tutela 11: 133-139.

GARDINER T. 2009: Macropterism of Roesel's bushcricket Metrioptera roeselii in relation to climate change and landscape structure in eastern England. Journal of Orthoptera Research 18: 95-102.

HARZ K. 1969. Die Orthopteren Europas (The Orthoptera of Europe) I. W. Junk, The Hague, 749 pp.

HARZ K. 1975. Die Orthopteren Europas (The Orthoptera of Europe) II. W. Junk, The Hague, 939 pp.

HOCHKIRCH A. 1997. Ein Vergleich der Heuschreckenfauna (Orthoptera: Saltatoria) gebrannter und ungebrannter Flächen in einem degeneriertem Hochmoor Nordwestdeutschlands (Lkr. Diepholz, Niedersachsen). Articulata 12: 155-162.

HOCHKIRCH A. \& ADORF F. 2007. Effects of prescribed burning and wildfires on Orthoptera in Central European peat bogs. Environmental Conservation 34: 225-235.

INGRISCH S. \& KÖHLER G. 1998. Die Heuschrecken Mitteleuropas. Die Neue Brehm Bücherei 629, Westarp Wissenschaften, Magdeburg, $460 \mathrm{pp}$.

KOČÁREK P., HOLUŠA J. \& VIDLIČKA L. 2005. Blattaria, Mantodea, Orthoptera \& Dermaptera of the Czech and Slovak Republics. Kabourek, Zlín, 348. pp

KRIŠTíN A. 1996. K poznaniu rovnokrídlovcov (Orthoptera) Chočských vrchov a prilahlých pohorí severozápadného Slovenska. Zbornik výsledkov 31. TOP-u, Kvačany: 64-67. 
KRIŠTíN A. 2001. Červený (ekosozologický) zoznam rovnokrídloveov (Orthoptera) Slovenska. Ochrana prírody 20, Suppl.: 103-104.

KRIŠTíN A. 2010. Rovnokrídlovee (Orthoptera) Tater, pp. 465-468. In: CHOvANCOVÁ B. (ed.), Encyklopédia Tatier, Baset, Praha, 639 pp.

KRIŠTíN A. \& HRÚZ V. (eds.) 2005. Rovnokrídlovce (Orthoptera) a modlivky (Mantodea) Pol'any: ekológia, rozšírenie a ochrana. ŠOP SR, Správa CHKO BR Pol'ana \& Ústav ekológie lesa SAV, Zvolen, 77 pp.

MARINI L., FONTANA P., SCOTON M. \& KLIMEK S. 2008. Vascular plant and Orthoptera diversity in relation to grassland management and landscape composition in the European Alps. Journal of Applied Ecology 45: 361-370.

MARINI L., FONTANA P., BATTISTI A. \& GASTON K.J. 2009. Response of orthopteran diversity to abandonment of semi-naturals meadows. Agriculture, Ecosystems and Environment 132: 232-236.

NADIG A., 1981. Die Insektenfauna des Hochmoores Balmoos bei Halse, Kanton Luzern. XIV. Orthoptera/Saltatoria. Entomologische Berichte Luzern 6: 87-89.

NADIG A., 1997. Zur Insektenfauna vom Hochmoor Forrenmoos, 970m, Eigental, Kanton Luzern. 3. Saltatoria (Heuschrecken). Entomologische Berichte Luzern 37: 103-104.

NIELSEN O.F. 2000. De danske graeshopper. Apollo books, Stensrup, 192 pp.

PONIATOWSKI D. \& FARTMANN T. 2011: Weather-driven changes in population density determine wing dimorphism in a bushcricket species. Agriculture, Ecosystems and Environment 145: 5-9.

RAMME W. 1931. Verlust oder Herabsetzung der Fruchtbarkeit bei nacropteren Individuen sonst brachypterer Orthopterenarten. Biologisches Zentralblatt 51: 533-540.

STRAKA V. 1992. K poznaniu rovnokrídleho hmyzu (Saltatoria) ŠPR Rojkovské rašelinisko. Ochrana prírody 1: 287289. (in Slovak).

STRAKA V. 1993. Rovnokrídlovce (Orthoptera) chráneného náleziska Rakšianske rašelinisko. Ochrana prírody Naturea tutela 2: 217-219.

STRAKA V. 1998. K poznaniu rovnokrídlovcov (Saltatoria) Prírodnej pamiatky Hradné bralo v Oravskom Podzámku. Zborník Oravského Múzea 15:163-165. (in Slovak).

ŠUŠLiK V. 1986. Ekológia niektorých druhov rovnokrídlovcov (Orthoptera) v západnej časti Liptova. Biologické práce, 32(3), s. 1-144. (in Slovak, English \& Russian abstr.)

TRNKA R. 2000. Ochrana biodiverzity rašelinísk v CHKO Horná Orava. In: STANOVÁ V. (ed.), Rašeliniská Slovenska, pp. 51-57. Daphne, Inštitút aplikovanej ekológie, Bratislava.

VICENIKOVÁ A. \& POLÁK P. (eds. ) 2003. Európsky významné biotopy na Slovensku. Štátna ochrana prírody, Banská Bystrica, $151 \mathrm{pp}$.

WEIDNER H. 1955. Macroptere Formen zweier gewöhnlich brachypterer Feldheuschrecken. Mitteilungen der Deutschen Entomologischen Gesellschaft 14: 19.

\section{STRESZCZENIE}

\section{[Prostoskrzydle (Orthoptera) torfowisk i mokrych ląk górskich w rejonie Orawy (póln- zach. Slowacja)]}

W pracy przedstawiono wyniki badań nad zasiedleniem cennych przyrodniczo torfowisk i mokrych ląk górskich przez prostoskrzydłe - szarańczaki i pasikoniki. W sumie na 16 stanowiskach w Orawie znaleziono 22 gatunki, w tym 16 na torfowiskach a 18 na mokrych górskich lakkach. Liczba gatunków na stanowisku wahala się od dwóch do czternastu. Szarańczak Euthystira brachyptera o szerokiej tolerancji ekologicznej występowal na wszystkich stanowiskach. Z pozostalych gatunków o dużej frekwencji Metrioptera roeselii i Omocestus viridulus byly notowane na $93.8 \%$ stanowisk, Chorthippus apricarius na $87.5 \%$ a Chorthippus parallelus na $75 \%$ stanowisk. Dwa górskie gatunki Miramella alpina i Metrioptera brachyptera są gatunkami wskaźnikowymi dla górskich ląk z Vaccinium myrtillus i torfowisk. W tym zimnym środowisku spodziewano się osobników zdwoma rodzajami skrzydel (makropteryzm) ibezskrzydlych. Największą liczbę takich osobników stwierdzono u gatunku Chrysochraon dispar, szczególnie w strefie ekotonu torfowiska w rezerwacie 'Rudné' (26.8\%). Analizowano występowanie i rozmieszczenie form z dobrze rozwiniętymi skrzydłami (f. makroptera) i ze skróconymi skrzydłami (f. brachyptera). Najwięcej form makropterycznych (26.8\%) stwierdzono u gatunku Chrysochraon dispar w strefie ekotonowej torfowiska Rezerwatu Przyrody Rudné. 